\title{
Iliac valve regurgitation disease: implications for the surgical approach of the venous insufficiency in the lower extremities
}

\author{
Doença da regurgitação valvar venosa ilíaca: implicações para o tratamento cirúrgico da insuficiência \\ venosa em membros inferiores
}

Otoni Moreira GOMES*, Eros Silva GOMES*

RBCCV 44205-607

\section{Abstract:}

Background: Varicose veins of the lower extremities is one of the most common circulatory diseases but no published reports describing the associated comparative rates of femoral and iliac valve regurgitation were found.

Objective: To study the occurrence of selective valve regurgitation in the external iliac vein, associated or not with insufficiency of the valves in the femoral or great saphenous veins.

Method: With the approval of the Ethics Committee of the São Francisco de Assis Cardiovascular Foundation, the venous system of the lower limbs of twenty-four female $(80 \%)$ and six male $(20 \%)$ patients aged between 21 and 71 years old (mean 39 years old), with varicose veins in the lower extremities, were studied with Color Flow Duplex Scanning (Esaote array; 7.5 MHz transducer; 2-dimensional, pulsed Doppler and color flow techniques). The aim was to investigate the regurgitation in the iliac, femoral, popliteal and great saphenous veins. The results were statistically analyzed using variance analysis and student $T$-test with a significance level of 0.05 .

Results: Iliac regurgitation $\geq 26.0 \mathrm{~cm} / \mathrm{s}$, which was present in 19 limbs, occurred isolated without reflux in the great saphenous ostium valve only in one case $(5.3 \%)$. In the cases with iliac regurgitation $<26.0 \mathrm{~cm} / \mathrm{s}$, the absence of regurgitation in the great saphenous vein ostium occurred in four limbs $(14.3 \%)$. Considering the total of 60 lower limbs studied, iliac regurgitation was observed in $47(78.3 \%)$ cases and dysfunction of the saphenous ostium valve in $45(75 \%)$ cases. Furthermore, saphenous ostium valve reflux without iliac regurgitation occurred only in three cases $(6.3 \%)$, which in only one case was above $25.9 \mathrm{~cm} / \mathrm{s}$.

Conclusion: In conclusion anomalies of the valvular function in the iliac veins present a significant correlation with the intensity of the insufficiency in the great saphenous vein ostium valve and the gravity of varicose veins in the lower limbs.

Descriptors: Varicose Veins. Iliac Vein, surgery. Iliac Vein, pathology. Venous Insufficiency

\section{Resumo}

Fundamentos: As varizes de membros inferiores constituem uma das mais comuns doenças circulatórias, contudo, até onde foi possível alcançar, não foram encontradas na literatura médica publicações científicas descrevendo a incidência comparativa de regurgitação valvar em veias ilíacas e safenas magnas.

Objetivo: Estudar a ocorrência de regurgitação valvar em veias ilíacas, associada ou não com insuficiência de válvulas em veias femoral ou safena magna.

Método: Em 30 pacientes portadores de varizes em membros inferiores, com idade entre 21 e 71 anos (média de 39 anos), sendo seis (20\%) do sexo masculino, foram estudados exames Duplex Scanning (Aparelho Esaote; transdutor de

Work done in Serviço do Coração / ServCor - Fundação Cardiovascular São Francisco de Assis. Belo Horizonte, MG, Brasil

* Da Fundação Cardiovascular São Francisco de Assis / ServCor, Belo Horizonte-MG, Brazil

Partially presented XI Meeting of the International Society for Heart Research, La Plata, Argentina, 2002

Correspondence address: Otoni Moreira Gomes. Rua José do Patrocínio, 522, Santa Mônica - Belo Horizonte - MG, Brazil.. CEP: 31525-160 Tel / Fax: (31) 3452-7143

E-mailservicor@servicor.com.br 
7,5 MHZ, com técnica bidimensional, doppler pulsado e fluxo a cores), analisando a regurgitação em veias ilíaca, femorais , safenas magnas e poplíteas.

Resultados: A regurgitação ilíaca importante, igual ou superior a $26,0 \mathrm{~cm} / \mathrm{s}$ presente em 19 membros, ocorreu isoladamente, sem refluxo na válvula ostial da veia safena em apenas um $(5,3 \%)$ caso. Nos casos com regurgitação ilíaca menor (Classes 1 a 3), a ausência de regurgitação ostial da veia safena ocorreu em quatro $(14,3 \%)$ membros. No total de 60 membros estudados, houve incidência de regurgitação ilíaca em $47(\mathbf{7 8 , 3 \%})$ casos, e de disfunção valvar ostial da safena

\section{INTRODUCTION}

Andreas Vesalius founded the first school of anatomy known in the West, in Pádua, Italy, having published his book 'De Humani Corporis Fabrica' in 1543, which revolutionized the knowledge of the human body. Among the most famous disciples of the Pádua School are Fabrízio d'Acquapendente and William Harvey from the beginning of the XVII century. Acquapendente described the valves of the venous system and Harvey interpreted the functional significance of these valves, describing for the first time the blood circulation.[1] Then, only after 200 years, VIRCHOW [2] in 1858, and MADELUNG [3] in 1884 improved the knowledge relating to venous diseases of the lower limbs. Virchow defined the bases of physiopathology of venous thrombosis and Madelung performed the first saphenectomy, which was later improved by KELLER, [4] introducing in 1905 phlebo-extraction by catheter. At this time, the importance of peripheral venous valve failure un the appearance of varicose veins of the lower limbs was already being considered. This also included the clinical rationale of degeneration of the deep vein valves and the communicating branches by the phlebitis inflammatory process, concepts that are considered correct until today. [5] The congenital anomaly of lower limb valves as a determining factor in varicose vein degeneration was first postulated by LUKE in 1941. [6,7] The absence of valves in the external iliac vein has also been included as a factor favoring varicose veins of the lower limbs [8].

The presence of valves in the external iliac vein segment and their rarity in the common iliac were described by FREIDREICH in 1882, [9] McMURRICH in 1906 [10]. DIDIO in 1951, [11], EGER \& CASPAR in 1943 [12] and POWELL \& LYNN in 1951 [13] based on anatomical observations, concluded that these valves play an important role in the etiopathology of varicose veins of the lower limbs, a condition refuted by BASMAJIAN in 1952, [14] also based only on anatomical studies. magna em 45 (75\%) casos. Contrariamente, a regurgitação ostial safena sem refluxo ilíaco ocorreu somente em três $(6,3 \%)$ casos, sendo em apenas um caso $(2,1 \%)$ superior a $25,9 \mathrm{~cm} / \mathrm{s}$.

Conclusão: Concluiu-se que as anomalias da função das válvulas em veias ilíacas representam o fator determinante de maior correlação com a intensidade da insuficiência valvular ostial da veia safena magna e com a gravidade das varizes em membros inferiores

Descritores: Varizes. Veia ilíaca, cirurgia. Veia ilíaca, patologia. Insuficiência venosa.
RISTOW et al. in 1979, [15] in a research using ultrasound, established a relationship between the weakness of valves in the iliofemoral segment and the persistence of symptoms in patients submitted to surgical treatment of varicose veins of the lower limbs.

In a review of publications related to the correlation of valve dysfunction of the iliac, femoral and great saphenous veins and varicose veins of the lower limbs, no reports were found. The objective of this investigation was to comparatively study the isolated or associated occurrence of regurgitation in these veins, using color flow duplex scanning in patients with varicose veins of the lower limbs.

\section{METHOD}

With the approval of the Ethics Committee of the São Francisco de Assis Cardiovascular Foundation, the venous systems of the lower limbs of twenty-four female (80\%) and six male (20\%) patients aged between 21 and 71 years old (mean age 39 years old) were investigated. All patients had varicose veins of the lower extremities, and were studied using Color Flow Duplex Scanning (Esaote array; 7.5 MHz transducer; 2-dimensional, pulsed Doppler and color flow techniques). An analysis of the regurgitation in the iliac, femoral, great saphenous and popliteal veins was performed. To evaluate the severity of the varicose veins the following severity index was employed: Class 1 - Micro and minimal varicose veins responsive to treatment by sclerotherapy; Class 2 - Small varicose veins, with indication of surgery for esthetic purposes; Class 3 - Large varicose veins with indication of formal surgery; Class 4-Complicated varicose veins. To assess the intensity of the venous valvular regurgitation, the following classification was adopted based on the reflux intensity (peak velocity) registered during effort from sudden and voluntary coughing, with the patient standing. The value considered was the maximum of three consecutive measurements: Class 0 -Absent; Class $1-1.0$ to $9.0 \mathrm{~cm} / \mathrm{s}$; Class $2-9.0$ to $17.0 \mathrm{~cm} / \mathrm{s}$; Class $3-18.0$ 
to $25.0 \mathrm{~cm} / \mathrm{s}$; Class $4-26.0$ to $34.0 \mathrm{~cm} / \mathrm{s}$; Class $5-35.0$ to $42.0 \mathrm{~cm} / \mathrm{s}$ and Class 6 - > $42.0 \mathrm{~cm} / \mathrm{s}$.

The results were statistically compared using variance analysis and student T-test with differences of 0.05 considered significant.

\section{RESULTS}

\section{Right Lower Limb}

Nine patients presented with iliac vein regurgitation with an intensity equal to or greater than $26.0 \mathrm{~cm} / \mathrm{s}$ (classes 4 to 6). The total severity index score of these patients was 27 points, an average of 3.37, which is a predominance of larger varicose veins in this sub-group.

There were 21 cases of patients with iliac vein regurgitation equal or less than $25.0 \mathrm{~cm} / \mathrm{s}$ (Classes 0 to 3) with an average of 1.53 for the gravity of varicose veins, predominating, however, with minimal and micro varicose veins (Table 1).

\section{Left Lower Limb}

Reflux of the iliac vein with intensity greater than or equal to $26.0 \mathrm{~cm} / \mathrm{s}$ occurred in eight cases, reaching 24 points in the assessment of the presence of varicose veins with a mean gravity of 3.0.

There were 22 cases of patients with iliac regurgitation of equal or less than $25 \mathrm{~cm} / \mathrm{s}$ with an average of $1.63 \mathrm{~cm} / \mathrm{s}$ and with a predomination of minimal and micro varicose veins (Table 1 and Figure 1).

Table 2 presents the results of the correlation among the ostial regurgitation in the great saphenous vein and the intensity of the gravity of the varicose veins of the lower limbs, observing that the intensity of reflux in classes 4 to 6 has a significant correlation with the greater caliber of the varicose veins.

Table 1. Correlation among veins and iliac valvular regurgitation.

\begin{tabular}{|c|c|c|c|c|c|}
\hline & & $\mathbf{N}$ & Points (Score) & Rate (mean) & \multirow[b]{2}{*}{$* * *$} \\
\hline \multirow{3}{*}{ RLL } & Regurgitation $>3 *$ & 9 & 25 & $3.1 * *$ & \\
\hline & Regurgitation $\leq 3 *$ & 15 & 29 & $1.7 \mathrm{~J}$ & \\
\hline & Absent & 6 & 5 & 1 & \\
\hline \multirow{3}{*}{ LLL } & Regurgitation $>3 *$ & 8 & 25 & 3.17 & $* * *$ \\
\hline & Regurgitation $\leq 3^{*}$ & 15 & 24 & $1.6 J$ & \\
\hline & Absent & 7 & 12 & 1.7 & \\
\hline
\end{tabular}

RLL and LLL: Right and Left Lower Limbs

* Greater than $25.9 \mathrm{~cm} / \mathrm{s}$

$* *$ Gravity rate of varicose veins

$* * *$ p-value $<0.05$

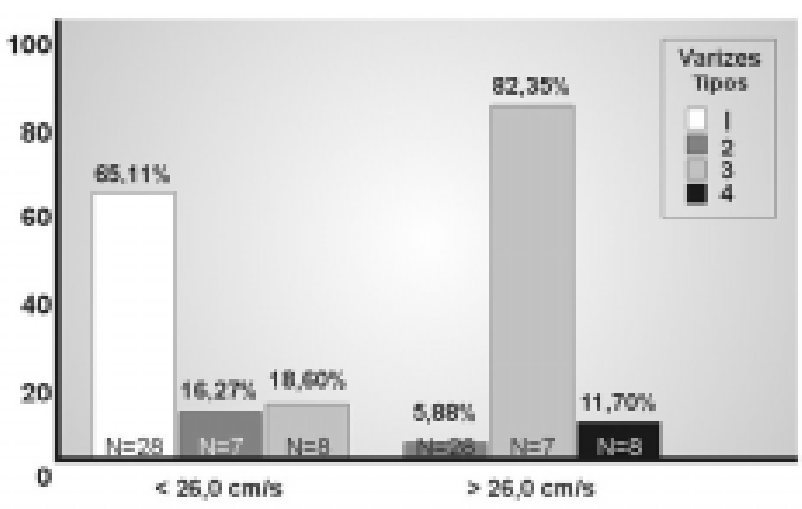

Fig. 1 - Correlation between iliac valvular regurgitation and severity of the varicose veins.

Table 2. Correlation among the varicose veins and saphenous ostial valvular regurgitation.

$\left.\begin{array}{lcccc}\hline & & \text { N } & \text { Points (Score) } & \text { Rate } \\ \hline \text { RLL } & \text { Regurgitation }>3 * & 10 & 31 & 3.01 \\ & \text { Regurgitation } \leq 3 * & 20 & 27 & 1.35\end{array}\right]^{* *}$

RLL and LLL: Right and Left Lower Limbs

* Regurgitation greater than class 3 (to $25.9 \mathrm{~cm} / \mathrm{s}$ )

$* *$ p-value $<0.05$;

Table 3 presents the correlation between the intensity of regurgitation of iliac valves and the ostial valvular dysfunction in the great saphenous veins. In right lower limbs, nine cases of iliac regurgitation with an intensity greater than $25.9 \mathrm{~cm} / \mathrm{s}$ (Classes 4 to 6 ) occurred. In these patients the saphenous regurgitation was in the 4 to 6 classes in eight cases and less than $26.0 \mathrm{~cm} / \mathrm{s}$ in only one individual.

Also in the right lower limbs, 16 cases of iliac regurgitation at an intensity of less than $26 \mathrm{~cm} / \mathrm{s}$ (Classes 1 to 3) occurred, which is similar to the great saphenous ostial in 19 patients and greater than $25.9 \mathrm{~cm} / \mathrm{s}$ in only two cases. Iliac reflux was present in five cases, in all of which there was also saphenous ostial reflux. In the left lower limbs, there were eight cases with iliac regurgitation greater than $25.9 \mathrm{~cm} / \mathrm{s}$, the great saphenous ostial valve presented similar regurgitation, and it was also equivalent in all the 22 cases with iliac regurgitation of less than $26 \mathrm{~cm} / \mathrm{s}$ (Table 4).

When considering the total of 60 studied limbs, iliac venous regurgitation was evidenced in $47(78.3 \%)$ and saphenous ostial in $44(73.3 \%)$ (Figure 2), defining the 
Table 3. Correlation between iliac and great saphenous ostial valvular regurgitation.

\begin{tabular}{cccccc}
\hline \multirow{2}{*}{ Regurgitation } & \multicolumn{2}{c}{ Iliac } & \multicolumn{2}{c}{ Saphenous } \\
& & $\mathbf{N}$ & $\%$ & $\mathbf{N}$ & $\%$ \\
\hline \multirow{2}{*}{ RLL $\quad<26.0 \mathrm{~cm} / \mathrm{s}$} & 8 & 26.6 & 10 & 40.0 \\
& Absent & 6 & 16.6 & 8 & 323.3 \\
& & & & & \\
\multirow{2}{*}{$\mathbf{L L L}$} & $<26.0 \mathrm{~cm} / \mathrm{s}$ & 8 & 26.6 & 12 & 33.3 \\
& $<26.0 \mathrm{~cm} / \mathrm{s}$ & 15 & 50.0 & 11 & 40.0 \\
& Absent & 7 & 23.3 & 7 & 26.6 \\
\hline
\end{tabular}

RLL and LLL: Right and Left Lower Limbs

Table 4. Regurgitation rate in iliac and saphenous veins.

\begin{tabular}{lcccc}
\hline Regurgitation & Absent & $\mathbf{2 5 . 9} \mathbf{~ c m} / \mathbf{s}$ & $\mathbf{2 5 . 9} \mathbf{~ c m} / \mathbf{s}$ \\
\hline \multicolumn{1}{l}{ Iliac } & RLL & 6 & 8 & 16 \\
& LLL & 7 & 8 & 15 \\
& RLL & 8 & 10 & 12 \\
Saphenous & LLL & 7 & 12 & 11 \\
\hline
\end{tabular}

RLL and LLL: Right and Left Lower Limbs

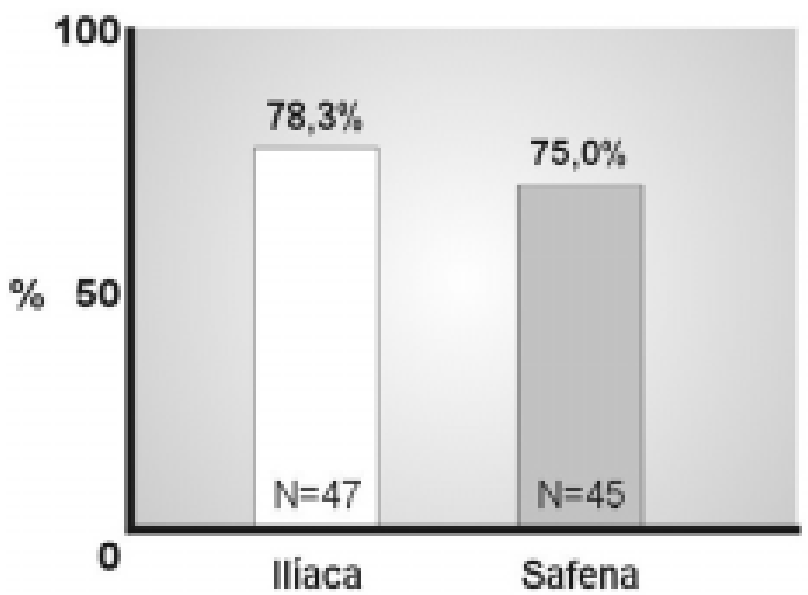

Fig. 2 - Correlation between iliac valvular and ostial saphenous vein regurgitation.

presence of saphenous ostial regurgitation in $93.6 \%$ of the cases of iliac valvular regurgitation. Of the 24 right lower limbs with iliac regurgitation, $22(91.7 \%)$ also presented with saphenous ostial regurgitation. In the left lower limbs,

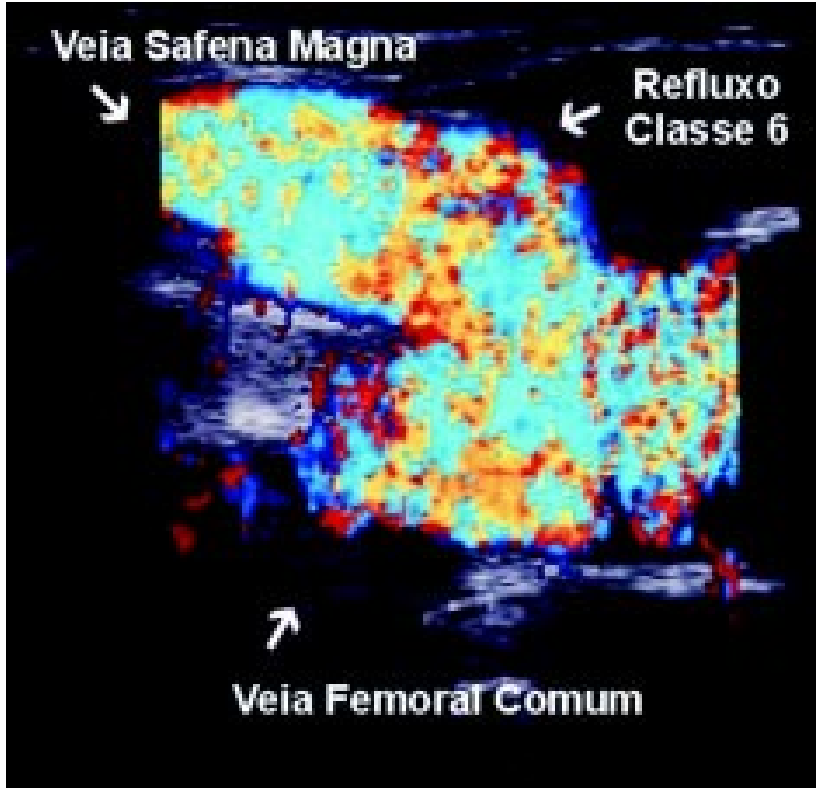

Fig 3. - Regurgitation in iliac veins and great saphenous veins.

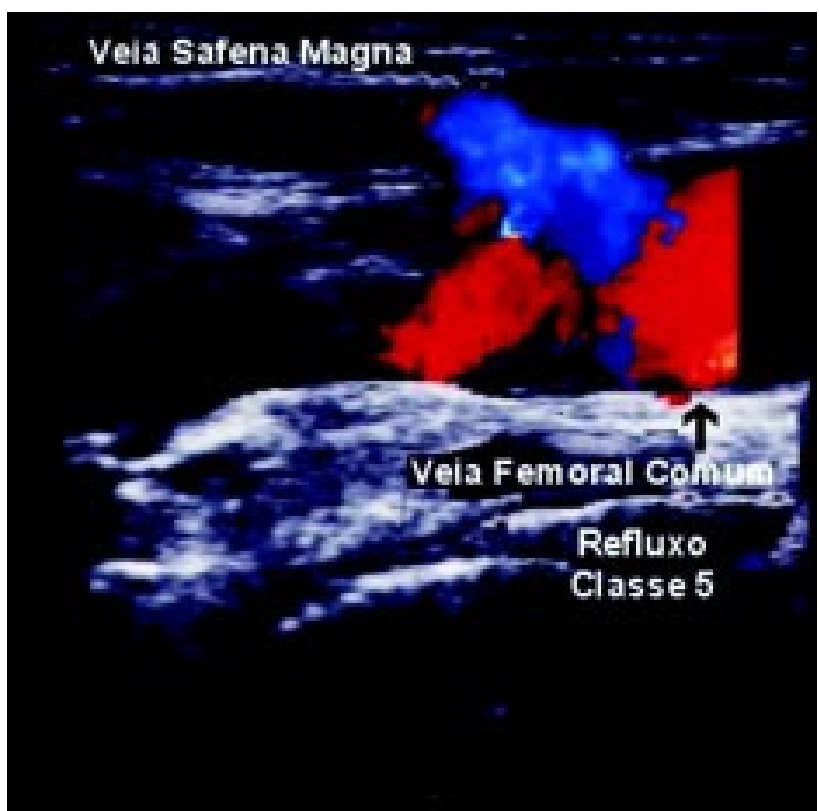

Fig. 4 - Selective iliac valvular regurgitation.

respective values of 23 and $22(95.6 \%)$ for iliac and saphenous ostial regurgitation were observed. These results demonstrated a significant association between iliac valvular regurgitation and great saphenous ostial dysfunction (Figure 3).

Iliac regurgitation of greater than or equal to $26.0 \mathrm{~cm} / \mathrm{s}$ present in 19 limbs occurred in isolation, without reflux of the saphenous ostial valve in only one $(5.3 \%)$ case (Figure 4). In the cases with lower iliac regurgitation (class 1 to 3 ), the absence of saphenous vein ostial regurgitation 


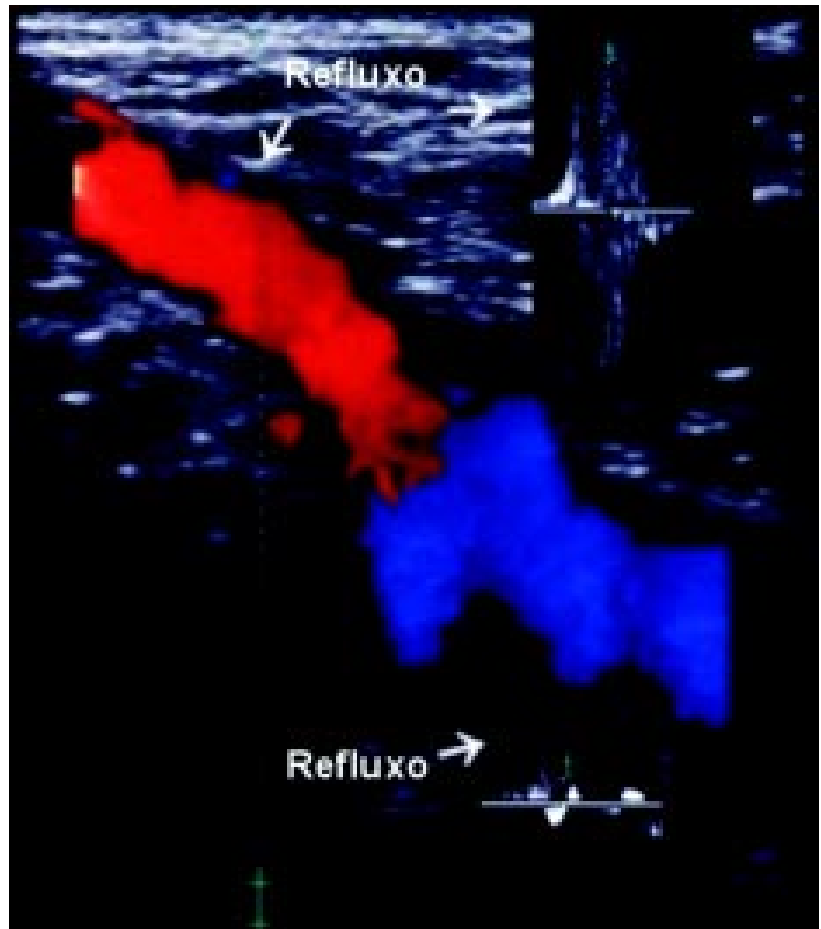

Fig. 5 - Selective reflux in the ostial valve of the great saphenous vein.

occurred in four (14.3\%) limbs. Of the total of 60 limbs studied, there was iliac regurgitation in 47 cases (78.3\%) and great saphenous ostial valvular dysfunction in 45 (75.0\%) of the cases. As opposed to saphenous ostial regurgitation without iliac reflux, which occurred in only three cases $(6.3 \%)$ where in only one case $(2.1 \%)$ it was greater than $25.9 \mathrm{~cm} / \mathrm{s}$ (Figure 5).

\section{COMMENTS}

The existence of valves in the venous system was described in the XVI century by Fabrício Acquapendente from the Anatomy School of Vesálio and, since then, they are designed in figures in the majority of anatomy, angiology and cardiovascular books. A notable fact, however, is the circumstance of not highlighting the difference in structure of the iliac valve, which is found at the start of the external iliac vein and is the strongest and most developed valve in all of the venous system.

Based on the venous valve topography described by McMURRICK in 1906 [10] and on the fact that the valves of the most expressive vessels of the organism, the aortic and the pulmonary artery, are at the start or the root of these valves, here we choose to denominate the iliac valve as the valve that is at the start of the external iliac vein, stressing its special morphologic structure, greater consistency [1214] and for the possible higher frequency of its presence or absence in the physiopathology of venous diseases of lower limbs. Other valves in the iliac venous segment are considered here as iliac valve accessories.

The position of the iliac valve is also special. To better guarantee its function, it is surrounded by resistant osteofibrosis structures, mainly represented by the inguinal ligament, at the front and by the iliopsoas and pectineal muscles over the hips behind. In these conditions the separation of its two cuspids is more difficult and the subsequent valvular failure with reflux significant. This is important as the iliac valve supports the complete weight of the column of blood of a standing individual, as accessory iliac valves are rare and there are no valves in the inferior vena cava, with the Eustachian valve at the junction of the right atrium, being only rudimentary.

Below the iliac valve there is the ostial valve of the great saphenous vein and the common femoral vein, at the transition with the superficial femoral vein. As the deep femoral vein can not have valves, the valves in the iliac vein represent an important protection against endothelial stress in supporting all the hydrostatic venous blood pressure.

Among the cardiac valvular diseases, stenosis, failure, double dysfunction, atresia and agenesis have been described. The iliac valvular disease has two main forms, which are valve failure and agenesis, diseases more common in the accessory iliac valves that are more fragile.

In this study, iliac valve regurgitation was seen to be present in $78.3 \%$ of the patients, all of whom suffered from lower limb varicose veins to varying degrees. As opposed to this, saphenous ostial regurgitation without iliac reflux occurred only in three cases (6.3\%), with only one case (2.1\%) greater than $25.9 \mathrm{~cm} / \mathrm{s}$. This condition favors the conception of a theory of the 'domino effect' for the non-infection and non-traumatic venous degeneration in lower limbs.

Congenital malformation of the iliac valve and its assessors creates a venous pressure hammer on the ostial valve of the great saphenous vein and on the valve at the junction of the common and superficial femoral veins, which are structurally weaker and less protected by supporting structures. Principally the great saphenous valve is inclined to dilatation and regurgitation. The valve at the start of the common femoral vein possesses a differential structural constitution, is protected by muscloaponeurotic structures of the thigh and it is more constant than the iliac vein valve, giving greater protection for the popliteal vein and its direct branches. This fact justifies the presence of reflux in the popliteal vein in only two patients (3.3\%) of the study group, with the most accentuated refluxes in the iliac valve. Thus, regurgitation of the iliac valve may suggest the distention of the common femoral vein and the great saphenous ostium, progressively deteriorating their valves. When the great saphenous valve has a better structure and resistance, the tension acts with a greater intensity on the ostial valve of the superficial femoral vein, which as it is more resistant reduces the development of the disease. On the other hand, the common femoral vein transmits the stress of the pressure to its branches, possessing valves with little 
consistency. Consequently, collateral venous dilations are formed, damaging the communicating perforating valves and this degeneration propagates to the great and lesser saphenous vein segments in the legs. This physiopathologic condition favors the explanation of clinical symptoms of paresthesia, the sensation of weight and orthostatic edema in patients without varicose veins and without reflux in the great saphenous vein, as all the tension is exerted on the region of drainage of the deep femoral vein, make the centripetal drainage of the communicators difficult. Although the appearance of varicose veins depend on other primary or secondary factors, which can depend on the constitutional resistance of the venous walls and the surrounding tissues which restrict dilation, two important researches support the previously mentioned domino theory. The first by FERREIRA, [17] who demonstrated the most common histopathologic alteration in varicose veins to be proliferation-type endothelial degeneration and fibrosis of the intima, explained by the continuous endothelial pressure stress. And secondly by RISTOW et al., [15] who demonstrated iliofemoral regurgitation in patients who persist with symptoms of varicose veins.

In a general analysis, it can be concluded that the anomalies of the valvular function in iliac veins represent the determining factor with the greatest correlation with failure of the ostial valve of the great saphenous vein and with the gravity of varicose veins of the lower limbs.

Also, with the aforementioned facts, it can be inferred that future epidemiological studies in different age ranges may indicate the patients with a greater potential risk to develop venous diseases of the lower limbs, such as, during pregnancy and the development of cardiomyopathies, permitting an earlier preventative treatment. New frontiers are opened for the treatment of patients evolving with more severe venous stasis of lower limbs too. The evidence in this study of bilateral iliac venous regurgitation raises the therapeutic hypothesis for the implantation of stents with valves in the iliac vein or the infrarenal inferior vena cava, by endovascular surgery or by a direct surgical procedure. This research is already being performed with the implantation of porcine aortic cuspid valvular segments preserved in glutaraldehyde, in the infra-renal vena cava of dogs with promising initial results. [18]

This investigation, however, did not permit other conclusions beyond the evidence that valvular dysfunction in the iliac venous segment was present in $78.3 \%$ of the studied lower limbs with varicose veins and that there is a direct relationship between the intensity of the venous reflux and the gravity of the varicose veins.

\section{BIBLIOGRAPHIC REFERENCES}

1. Oliveira AB. A evolução da Medicina. São Paulo: Pioneira, 1981.

2. Virchow R. Die Cellularpathologieund Gewebelehre. Berlin: Hirschwald, 1858. In: Garrison FH, Morton LT. A medical bibliography. Londres: Grafton, 1943.
3. Madelung. In: Juergens JL, Spittell Jr. JA, Fairbairn II JF. Peripheral vascular diseases. Philadelphia: WB Saunders, 1980.

4. Keller WL. A new method of extirpating the internal saphenous and similar veins in varicose conditions: a preliminary report. NY Med J 1905; 82:385-6.

5. Maffei FHA, Lastória S, Yoshida WB, Rollo HA. Doenças vasculares periféricas. Rio de Janeiro: MEDSI, 1987.

6. Luke JC. The diagnosis of chronic enlargement of the leg with description of a new syndrome. Surg Gynecol Obstet 1941; 73: $472-80$

7. Luke JC. The deep vein valves. Surgery 1951; 29:381-91.

8. Garrido MBM. Anatomia do sistema venoso dos membros inferiores. In: Maffei FHA, Lastória S, Yoshida WB, Rollo HA. Doenças vasculares periféricas. Rio de Janeiro: MEDSI, 1987.

9. Friedreich N. Ueber das Verhalten der Klappen den Cruralvenen, sowie ueber das Verkommen von Klappen in den grossen Venanstaemmen des Uterleibes. Morph Jjahrb 1882; 7: 323-5.

10. McMurrich JP. The valves of the iliac vein. Br Med J 1906; 2: $1699-700$

11. Di Dio LJA. Válvulas das veias ilíacas comuns em brancos, negros e mulatos. Rev Hosp Clin Fac Med S Paulo 1951; 4: 343-59.

12. Eger SA, Casper SI. The etiology of varicose veins from an anatomic aspect, based on dissection of 38 adult cadavers. JAMA 1943; 123: 148-58.

13. Powell T, Lynn RB. The valves of the external iliac femoral and upper third of the popliteal veins. Surg Gynecol Obstet 1951; 92: 453-63.

14. Basmajian IV. The distribution of valves in the femoral external iliac and common iliac veins and their relationship to varicose veins. Surg Gynecol Obstet 1952; 95: 537- 45.

15. Ristow AVB, Arruda AM, Albuquerque JT, Medina AL. Varizes primárias: 10 anos de experiência com o tratamento cirúrgico. Rev Assoc Med Bras 1979; 25: 216-8.

16. Gomes OM, Gomes ES. Iliac valve regurgitation disease. In: $X$ Meeting of the International Society for Heart Research - Latin American Section; 2002; La Plata, Argentina.

17. Garrido MBM. Patologia e diagnóstico de varizes dos membros inferiores. In: Maffei FHA, Lastória S, Yoshida WB, Rollo HA. Doenças vasculares periféricas. Rio de Janeiro: MEDSI, 1987.

18. Gomes OM, Zandim R, Rodrigues JBT, Miranda ED, Barros D, Oliveira DMA. Implante de cúspide valvar heteróloga em veia cava inferior infra-renal - Estudo experimental em cães. XIX Congresso Norte-Nordeste de Cirurgia Cardiovascular / XIX Encontro dos Discípulos do Professor Zerbini, Belém-PA, 2001. 